\title{
Application of a screening test for antibody to hepatitis B core antigen
}

\author{
B. J. COHEN AND Y. E. COSSART
}

From the Virus Reference Laboratory, Central Public Health Laboratory, Colindale Avenue, London NW9 5HT

SUMMARY Hepatitis B core antigen ( $\mathrm{HBcAg}$ ) was prepared from human liver tissue and used in an immunoelectro-osmophoresis screening test to detect antibody to $\mathrm{HBcAg}$ (anti-HBc) in patients with evidence of liver disease and in blood donors. With the exception of two immunosuppressed $\mathrm{HBsAg}$ carriers, anti-HBc was found in all cases of hepatitis B infection even when HBsAg was detectable only by radioimmunoassay. Non-specific reactions were observed in 'non-B' hepatitis but, in spite of this problem, anti-HBc screening was considered a useful addition to routine tests in the clinical hepatitis laboratory.

The appearance of antibody to hepatitis B core antigen (anti-HBc) during acute hepatitis B infection has been clearly documented in both man (Hoofnagle et al., 1973) and the chimpanzee (Markenson et al., 1975). It has also been found that antibody is regularly present in the sera of established carriers (Hoofnagle et al., 1973). It therefore seems that determination of anti-HBc might provide a sensitive indication of active or recent hepatitis B infection, but so far its application in routine laboratories has been very limited.

Several methods for detecting anti-HBc have been described, including fluorescent antibody (Brzosko et al., 1973), complement fixation (Hoofnagle et al., 1973), immunoelectro-osmophoresis (Budkowska et al., 1974), and radio-immune precipitation (Moritsugu et al., 1975). Hepatitis B core antigen (HBcAg) for the tests has been obtained from either human or chimpanzee liver or, more rarely, from serum rich in Dane particles.

This paper describes a simple method of extracting $\mathrm{HBcAg}$ from human liver and the application of an immunoelectro-osmophoresis (IEOP) technique for testing clinical specimens for anti-HBc.

\section{Material and methods}

PREPARATION OF CORE ANTIGEN

A $10 \%$ extract of postmortem liver tissue from an immunosuppressed HBsAg carrier was prepared by grinding with sand and distilled water in a mortar. The extract was filtered through muslin, frozen,

Received for publication 24 March 1977 thawed three times, and clarified by low-speed centrifugation ( $1500 \mathrm{~g}$ for 30 minutes). The supernate was then centrifuged at $200000 \mathrm{~g}$ for two hours. The resulting pellet was resuspended in distilled water and the cycle of low- and high-speed centrifugations was repeated. The final high-speed pellet was resuspended in $1 / 10$ th of the original volume of distilled water and was used as the 'partially purified' $\mathrm{HBcAg}$. Further purification was attained by $\mathrm{CsCl}$ density gradient centrifugation.

SEROLOGICAL TESTS FOR ANTI-HBC IEOP was performed by the technique developed for HBsAg detection (Pesendorfer et al., 1970). Screening tests for anti-HBc were carried out using both the 'partially purified' $\mathrm{HBcAg}$ (used at two to four times its IEOP titre) and 'normal' antigen control prepared from HBsAg negative liver tissue. All positive reactions were confirmed with $\mathrm{CsCl}$ gradient purified $\mathrm{HBcAg}$, and selected reactions were further checked by electron microscopy of the precipitin line (Fig. 1).

Complement fixation (CF) (Grist et al., 1975) and immune electron microscopy (IEM) (Almeida et al., 1969) were performed by conventional methods.

HBsAg and anti-HBs tests were performed by IEOP and radioimmunoassay (RIA) using commercially available reagents (Abbott Laboratories).

$\mathrm{HBeAg}$ and anti-HBe were detected by immunodiffusion (Magnius and Espmark, 1972).

SPECIMENS EXAMINED FOR ANTI-HBC

Sera submitted for hepatitis B testing were selected in the following categories: 


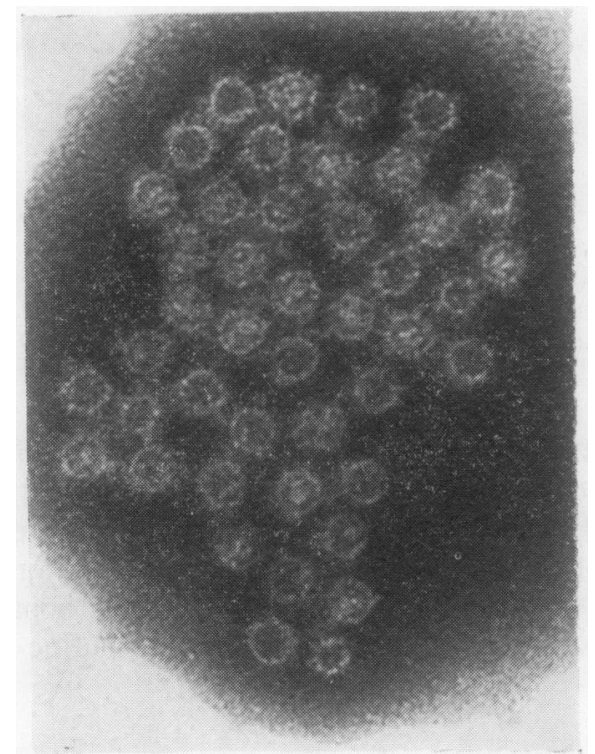

Fig. $1 \mathrm{HBcAg}$ particles aggregated with antibody in precipitin line from IEOP test ( $\times 180$ 000).

$1 \mathrm{HBs} A g$-positive acute hepatitis

2 HBsAg-negative acute hepatitis

3 HBsAg-positive chronic liver disease

4 HBsAg-negative chronic liver disease

5 Blood donors found to be negative for both HBsAg and anti-HBs on initial IEOP screening test.

\section{Results}

The 'partially purified' $\mathrm{HBcAg}$ had a titre of $1: 32$ by IEOP and $1: 320$ by CF when tested against a reference antiserum (National Institutes of Health, USA). EM examination revealed typical $27 \mathrm{~nm}$ particles free from antibody coating (Fig. 2). HBsAg could not be detected by CF or IEOP but the final extract had a RIA ratio of $2 \cdot 5$. It was negative for anti-HBs (RIA ratio $<2 \cdot 1$ ), $\mathrm{HBeAg}$, and antiHBe.

The results obtained using the IEOP screening test are given in Table 1 . Anti-HBc was readily detectable in all specimens which contained HBsAg whether the antigen was present in high or low titre.

\section{BLOOD DONORS}

Very few persons without liver disease were found to possess anti-HBc. Of the seven detected out of 929 blood donors, one was found to have low titred HBsAg and three others anti-HBs. Of the three remaining positives by the screening test, one could not be confirmed by immune electron microscopy.

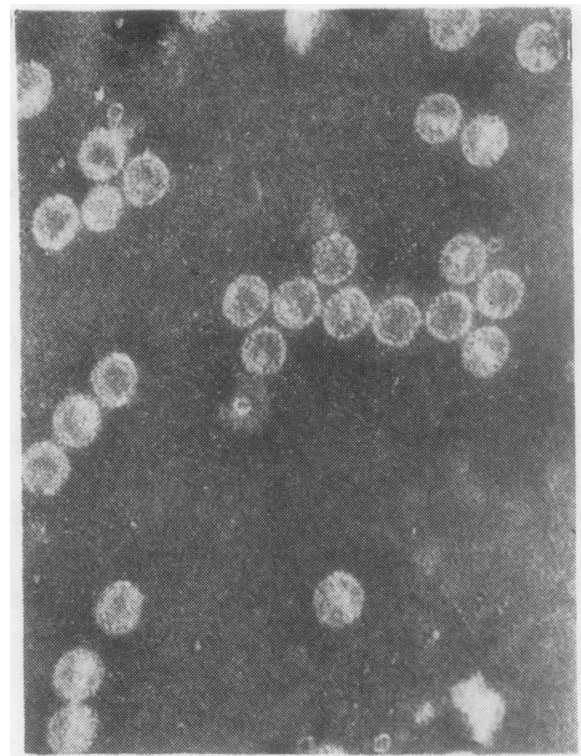

Fig. $2 \mathrm{HBcAg}$ particles free from antibody in 'partially purified' liver extract $(\times 180000)$.

\section{ACUTE HEPATITIS B}

The admission specimen from all 50 patients who were $\mathrm{HBs} \mathrm{Ag}$ positive also contained anti-HBc by electrophoresis and the results could be confirmed by immune electron microscopy. The pattern of antibody response in five representative cases is illustrated in Fig. 3.

\section{ACUTE HBSAg NEGATIVE HEPATITIS}

Ten of the 20 admission specimens from patients who were $\mathrm{HBsAg}$ negative were anti-HBc positive by IEOP. Table 2 shows the results of confirmatory tests on these sera.

Four specimens were confirmed positive by IEM and they were also shown to contain anti-HBs by RIA. Therefore, the presence of anti-HBc in these HBsAg negative patients probably indicated past hepatitis B infection.

The remaining six positives from the IEOP screening test could not be confirmed by CF or IEM

Table 1 Results of anti-HBc in different categories of patients

\begin{tabular}{llll}
\hline Category & $\begin{array}{l}\text { HBsAg } \\
\text { status }\end{array}$ & $\begin{array}{l}\text { Number } \\
\text { tested }\end{array}$ & $\begin{array}{l}\text { Anti-HBc } \\
\text { positive }\end{array}$ \\
\hline Acute hepatitis & RIA + & 50 & $50(100 \%)$ \\
Acute hepatitis & RIA - & 20 & $10(50 \%)$ \\
Chronic hepatitis & RIA + & 20 & $20(100 \%)$ \\
Chronic hepatitis & RIA - & 66 & $14(21 \%)$ \\
Blood donor & IEOP - & 929 & $7(0 \cdot 75 \%)$ \\
\hline
\end{tabular}



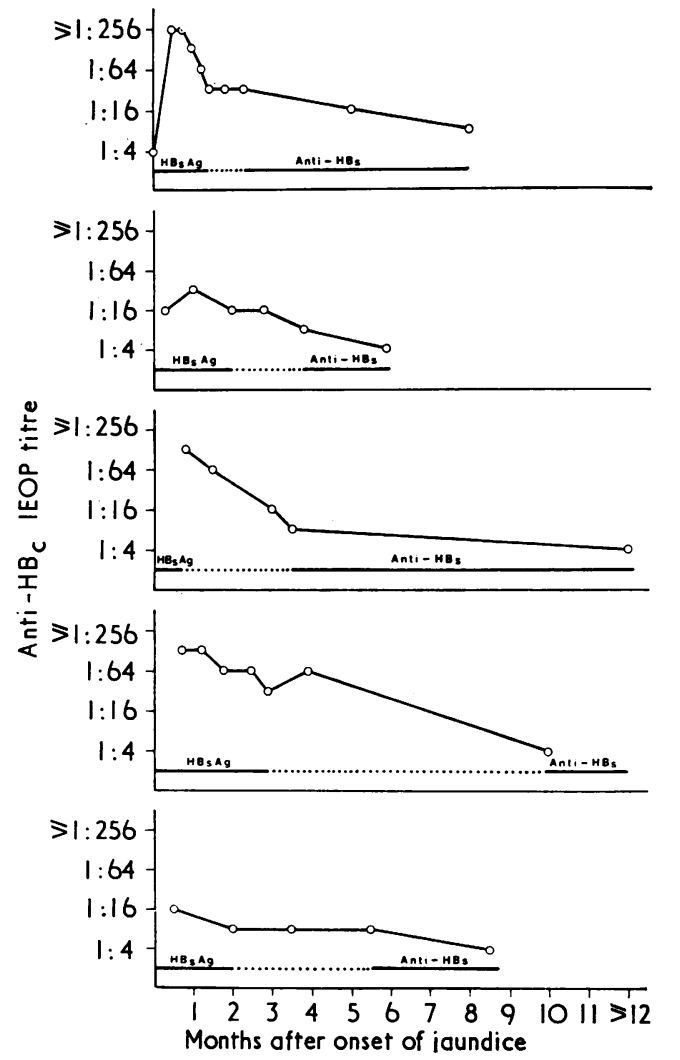

Fig. 3 Pattern of anti- $\mathrm{HBc}$ response in five representative cases of acute hepatitis $B$.

and were negative for anti-HBs by RIA. Two of them reacted with an antigen from normal liver. In addition, follow-up samples obtained 18 months later from two of the six patients were negative for anti-HBc. No further samples could be obtained

Table 2 Investigations of anti-HBc positive sera from $\mathrm{HBs} \mathrm{Ag}$ negative patients with acute hepatitis

\begin{tabular}{|c|c|c|c|c|c|c|}
\hline \multirow[t]{2}{*}{ Patient } & \multirow[t]{2}{*}{ Age } & \multirow[t]{2}{*}{ Sex } & \multirow{2}{*}{$\begin{array}{l}\text { Anti-HBs } \\
R I A\end{array}$} & \multicolumn{3}{|c|}{$A n t i-H B c$} \\
\hline & & & & IEOP & $C F$ & IEM \\
\hline 1 & 34 & $\mathbf{M}$ & + & Neat & $\mathbf{A} / \mathbf{C}^{*}$ & + \\
\hline 2 & 22 & $\mathbf{M}$ & + & $1: 4$ & $\mathrm{~A} / \mathrm{C}$ & + \\
\hline 3 & 20 & $\mathbf{M}$ & + & $1: 128$ & $>1: 256$ & + \\
\hline 4 & 55 & $\mathbf{M}$ & + & $1: 2$ & $<1: 8$ & + \\
\hline 5 & 23 & $\mathbf{M}$ & - & $1: 2$ & $<1: 8$ & - \\
\hline 6 & 23 & $\mathbf{M}$ & - & $1: 2 \dagger$ & $<1: 8$ & - \\
\hline 7 & 40 & $\mathbf{M}$ & - & $1: 2$ & $<1: 8$ & - \\
\hline 8 & 2 & $\mathbf{M}$ & - & $1: 4$ & $<1: 8$ & - \\
\hline 9 & 50 & $\mathbf{M}$ & - & $1: 8 † \ddagger$ & $<1: 8$ & - \\
\hline 10 & 50 & $\mathbf{F}$ & - & $1: 2 \ddagger$ & $<1: 8$ & - \\
\hline
\end{tabular}

from the other four. It was concluded that six of the 10 positives in $\mathrm{HBs} A \mathrm{~g}$ negative patients were not actually due to the presence of anti-HBc. They may have been 'false-positives' due to non-specific reactions.

\section{CHRONIC LIVER DISEASE}

All 20 patients with HBsAg-positive chronic liver disease were found to be positive for anti-HBc (Fig. 4).

Of 66 patients with $\mathrm{HBsAg}$-negative chronic liver disease 14 reacted in the IEOP screening test but the titres were low (Fig. 4). Results of confirmatory tests on the 14 sera are shown in Table 3. Because a high proportion $(65 \%)$ of these patients were antiHBs positive all the group were tested (Table 4). A much lower proportion (13\%) of the anti-HBc negative group was anti-HBs positive but this is still higher than the $6 \%$ level found in normal adults in this country (Cossart, 1976).

\section{Discussion}

This study was undertaken firstly to establish the practicability of routine tests for anti-HBc and secondly to assess their value in clinical practice.

An electrophoresis test was chosen because many hepatitis laboratories have considerable experience with this method which is simple, quick, and economical. The problem of producing a substantial amount of $\mathrm{HBcAg}$ was solved by obtaining livers from postmortem examinations on $\mathrm{HBsAg}$-positive subjects. Two of 24 were suitable, that is, contained abundant $\mathrm{HBcAg}$ but scanty $\mathrm{HBsAg}$ in patients with little, or no, detectable anti-HBc. In our experience, this combination was found only in the two patients who yielded the antigen preparations used for the tests. They were both heavily immunosuppressed.

The crude antigen from the simple extraction procedure was almost as satisfactory as the more highly purified one but both gave some non-specific precipitin lines in which antibody-coated cores could not be found by electron microscopy. A control antigen extracted from a normal liver also gave lines with some of the false positive sera, which were rare among blood donors $(0.1 \%)$ but frequent in patients with acute hepatitis $(30 \%)$ and not uncommon in chronic hepatitis (6\%). Similar non-specific reactions have been reported when sera from the acute phase of hepatitis have been tested against other antigens (Almeida et al., 1974). They were not eliminated by inactivating the $\mathrm{HBcAg}$ for $56^{\circ}$ for 30 minutes.

Despite this problem, anti-HBc tests have proved very useful in evaluating equivocal $\mathrm{HBs} \mathrm{Ag}$ results. 


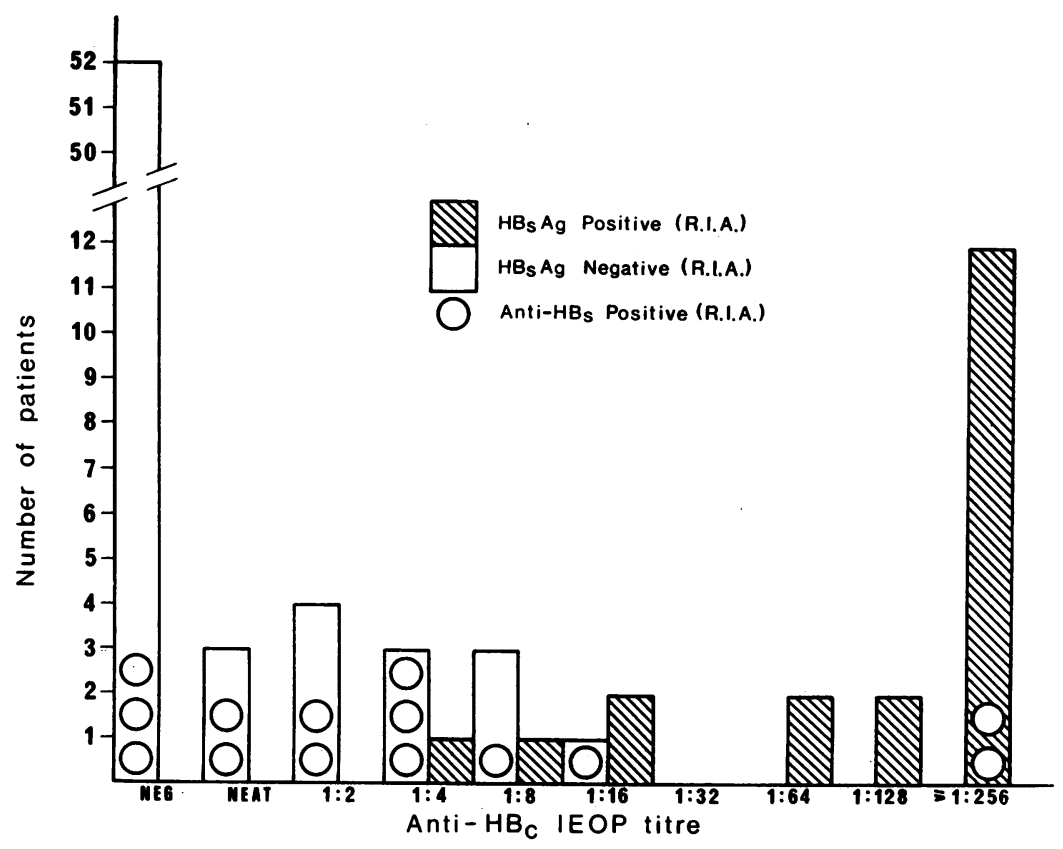

Fig. 4 Anti-HBc titres in patients with chronic liver disease.

Table 3 Investigations of anti-HBc positive serum from HBs Ag negative patients with chronic liver disease

\begin{tabular}{|c|c|c|c|c|c|c|c|}
\hline \multirow[t]{2}{*}{ Patient } & \multirow[t]{2}{*}{ Age } & \multirow{2}{*}{\multicolumn{2}{|c|}{ Sex Illness }} & \multirow{2}{*}{$\begin{array}{l}\text { Anti- } \\
\text { HBs } \\
\text { RIA }\end{array}$} & \multicolumn{3}{|c|}{$A n t i-H B c$} \\
\hline & & & & & IEOP & $C F$ & IEM \\
\hline 1 & 54 & $\mathbf{F}$ & Cirrhosis & + & $1: 4$ & $1: 8$ & + \\
\hline 2 & 43 & $\mathbf{F}$ & Cirrhosis & + & $1: 4$ & $1: 16$ & + \\
\hline 3 & 63 & $\mathbf{M}$ & Cirrhosis & + & $1: 8$ & $1: 64$ & + \\
\hline 4 & 65 & $\mathbf{F}$ & $\begin{array}{c}\text { Chronic active } \\
\text { hepatitis }\end{array}$ & + & $1: 4$ & $1: 8$ & + \\
\hline 5 & $4 \dot{y}$ & $\mathbf{F}$ & Cirrhosis & + & $1: 2$ & $1: 8$ & + \\
\hline 6 & 21 & $\mathbf{F}$ & $\begin{array}{l}\text { Chronic active } \\
\text { hepatitis }\end{array}$ & + & $1: 16$ & $1: 128$ & + \\
\hline $\begin{array}{l}7 \\
8\end{array}$ & $\begin{array}{l}32 \\
47\end{array}$ & $\begin{array}{l}\mathbf{M} \\
\mathbf{F}\end{array}$ & $\begin{array}{l}\text { Persistent hepatitis } \\
\text { Chronic active }\end{array}$ & + & $1: 2$ & $\mathrm{~A} / \mathrm{C}$ & + \\
\hline & & & hepatitis & + & Neat & $\mathrm{A} / \mathrm{C}$ & + \\
\hline 9 & 19 & $\mathbf{M}$ & $\begin{array}{l}\text { Chronic active } \\
\text { hepatitis }\end{array}$ & - & $1: 8$ & $1: 32$ & + \\
\hline 10 & 63 & $\mathbf{F}$ & $\begin{array}{c}\text { Chronic active } \\
\text { hepatitis }\end{array}$ & + & Neat & $<1: 8$ & - \\
\hline 11 & 70 & $\mathbf{F}$ & $\begin{array}{l}\text { Chronic active } \\
\text { hepatitis }\end{array}$ & - & Neat & $<1: 8$ & + \\
\hline 12 & 70 & $\mathbf{M}$ & $\begin{array}{l}\text { Chronic liver } \\
\text { disease }\end{array}$ & - & $1: 2$ & $<1: 8$ & - \\
\hline 13 & 61 & $\mathbf{F}$ & Hepatic failure & - & $1: 8$ & $<1: 8$ & - \\
\hline 14 & 50 & $\mathbf{F}$ & Cirrhosis & - & $1: 2$ & $<1: 8^{*}$ & - \\
\hline
\end{tabular}

Table 4 Chronic hepatitis HBsAg RIA negative

\begin{tabular}{lccc}
\hline & $\begin{array}{l}\text { Anti-HBs } \\
R I A+\end{array}$ & $\begin{array}{l}\text { Anti-HBs } \\
\text { RIA }-\end{array}$ & Total \\
\hline Anti-HBc & & 5 & \\
IEOP + & 9 & 55 & 14 \\
Anti-HBc & 7 & 50 & 52 \\
IEOP - & 16 & 66 \\
Total & &
\end{tabular}

A negative anti-HBc result in patients who are not immunosuppressed virtually excludes the presence of HBs antigenaemia.

A larger study of anti-HBc tests for screening blood donors is needed. Our results suggest that it is much cheaper, simpler, and quicker than radioimmunoassay or enzyme-immunoassay for $\mathrm{HBsAg}$, yet it detected all the hepatitis $\mathrm{B}$ carriers detected by these cumbersome methods. It is not known whether persons with anti-HBc who are $\mathrm{HBsAg-negative} \mathrm{are}$ infective. We were unable to obtain specimens from the four patients transfused with material in this category, but it was possible to establish that none developed clinical hepatitis during the ensuing nine months.

It is difficult to interpret the anti-HBc results in patients with HBs-Ag-negative chronic liver disease since little was known about their country of origin or previous history. However, they certainly differ from the general population as regards presence of both anti-HBs $(23 \%$ positive; compared with normal $6 \%)$ and anti-HBc (21\% positive; compared with $0.75 \%$ normal). This suggests that hepatitis B infection may have been the initial liver injury in a significant proportion of these patients.

In general, our findings show that routine anti-HBc tests can be introduced relatively easily, and that they offer useful additional information about patients with suspected hepatitis B infection. 
We are grateful to Professor E. A. Wright, King's College Hospital, for the supply of postmortem livers, and $\mathrm{Dr}$ K. Ll. Rodgers, South London Transfusion Centre, who provided specimens from blood donors.

\section{References}

Almeida, J. D., Zuckerman, A. J., Taylor, P. E., and Waterson, A. P. (1969). Immune electron microscopy of the Australia-SH (serum hepatitis) antigen. Microbios, 1, 117-123.

Almeida, J. D., Gay, F. W., and Wreghitt, T. G. (1974). Pitfalls in the study of hepatitis A. Lancet, 2, 748-750.

Brzosko, W. J., Madaliński, K., Krawczyński, K., and Nowoslawski, A. (1973). Duality of hepatitis B antigen and its antibody. I. Immunofluorescence studies. Journal of Infectious Diseases, 127, 424-428.

Budkowska, A., Walicka, B., Domaniewska, G., and Brzosko, W. J. (1974). Immunoelectro-osmophoresis for the detection of antibody to hepatitis B core antigen. New England Journal of Medicine, 290, 1489-1490.
Cossart, Y. E. (1976). Unpublished.

Grist, N. R., Ross, C. A. C., and Bell, E. J. (1975). Diagnostic Methods in Clinical Virology, 2nd edition. Blackwell Scientific Publications, Oxford.

Hoofnagle, J. H., Gerety, R. J., and Barker, L. F. (1973). Antibody to hepatitis-B-virus core in man. Lancet, 2, 869-873.

Magnius, L. O. and Espmark, J. A. (1972). New specificities in Australia antigen positive sera distinct from the le Bouvier determinants. Journal of Immuno$\log y, 109,1017-1021$.

Markenson, J. A., Gerety, R. J., Hoofnagle, J. H., and Barker, L. F. (1975). Effects of cyclophosphamide on hepatitis $B$ virus infection and challenge in chimpanzees. Journal of Infectious Diseases, 131, 79-87.

Moritsugu, Y., Gold, J. W. M., Wagner, J., Dodd, R. Y., and Purcell, R. H. (1975). Hepatitis B core antigen. Detection of antibody by radioimmunoprecipitation. Journal of Immunology, 114, 1792-1798.

Pesendorfer, F., Krassnitsky, O., and Wewalka, F. (1970). Immunoelectrophoretic methods. Bulletin of the World Health Organization, 42, 974-975. 